\title{
Petrology of dioritic, tonalitic and trondhjemitic gneisses from Encantadas Complex, Santana da Boa Vista, southernmost Brazil: Paleoproterozoic continental-are magmatism
}

\author{
RUY P. PHILIPP ${ }^{1}$, MARCELO LUSA ${ }^{2}$ and LAURO V.S. NARDI ${ }^{1}$ \\ ${ }^{1}$ Universidade Federal do Rio Grande do Sul, Instituto de Geociências \\ Centro de Estudos em Petrologia e Geoquímica (CPGq), Av. Bento Gonçalves, 9.500, Bairro Agronomia \\ 91501-970 Porto Alegre, RS, Brasil \\ ${ }^{2}$ Universidade Federal do Rio Grande do Sul, Pós-Graduação em Geociências, Instituto de Geociências \\ Av. Bento Gonçalves, 9.500, Bairro Agronomia, 91501-970 Porto Alegre, RS, Brasil \\ Manuscript received on February 26, 2007; accepted for publication on July 18, 2008; \\ contributed by LAURO V.S. NARDI*
}

\begin{abstract}
The Encantadas Complex is a unit composed of dioritic, tonalitic and trondhjemitic gneisses with minor hornblendite. This complex is intruded by granites of Neoproterozoic age. Major and trace element data indicate metaluminous to slightly peraluminous composition related to the medium-K calc-alkaline series. Compositional parameters are consistent with a common evolution from less differentiated magmas, probably through fractional crystallization. The orthogneisses show $\mathrm{La}_{\mathrm{N}} / \mathrm{Yb}_{\mathrm{N}}$ ratios from 10 to $50, \mathrm{~K}_{2} \mathrm{O} / \mathrm{Na}_{2} \mathrm{O}$ varying from 1.1 to 3.0 , $\mathrm{Y}$ contents from 3 to $39 \mathrm{ppm}, \mathrm{Yb}$ from 0.3 to 3.7, and $\mathrm{Lu}$ with contents in the range 0.06 and $0.54 \mathrm{ppm}$. Such geochemical features are similar to those of Archaean tonalitic rocks and are usually described in rocks formed by partial melting of mafic rocks under high-pressure conditions leaving an eclogitic residue. The presence of diorites and hornblendites, associated to tonalitic and trondhjemitic gneisses suggests, on the other hand, that tonalitic magmas could be formed by hornblende-controlled fractionation of hydrous basaltic magmas. Tonalitic gneisses show U-PbSHRIMP zircon age of $2,263 \pm 6 \mathrm{Ma}$ for igneous crystallization and 2,045 $\pm 10 \mathrm{Ma}$ for the metamorphism. The geochemical parameters, tectonic and geochronological features of Encantadas Complex are consistent with magmas derived from mantle metasomatized by subduction-related fluids in a continental-arc.
\end{abstract}

Key words: continental arch, crustal evolution, Encantadas gneisses, Paleoproterozoic, Petrology, TTG.

\section{INTRODUCTION}

The orthogneisses of Santana da Boa Vista, southernmost Brazil were described by Ribeiro et al. (1966) and related to the central part of Santana da Boa Vista Dome by Jost and Bitencourt (1980) (Fig. 1). This dome is a $\mathrm{N} 30^{\circ} \mathrm{E}$ elongate structure, approximately $50 \mathrm{~km}$ long and 8 to $15 \mathrm{~km}$ wide (Fig. 2).

\footnotetext{
*Member Academia Brasileira de Ciências

Correspondence to: Ruy Paulo Philipp

E-mail: ruy.philipp@ufrgs.br

Present address: Rua Ângelo Possebon, 105/203, 92310-140 Canoas, RS, Brasil
}

The orthogneisses referred to as Encantadas Complex, are metatonalites and metatrondhjemites with minor amphibolites and meta-ultramafic hornblende-rich rocks of Paleoproterozoic age. The complex is crosscut by monzogranites and syenogranites of Neoproterozoic age (R. Machado, A.R.S. Fragoso Cesar and U. Faccini, unpublished data, Remus et al. 1990, Porcher and Fernandes 1990).

The contact of Encantadas Complex gneisses with metasedimentary and metavolcanic rocks of the Porongos Metamorphic Complex is marked by low-angle duc- 


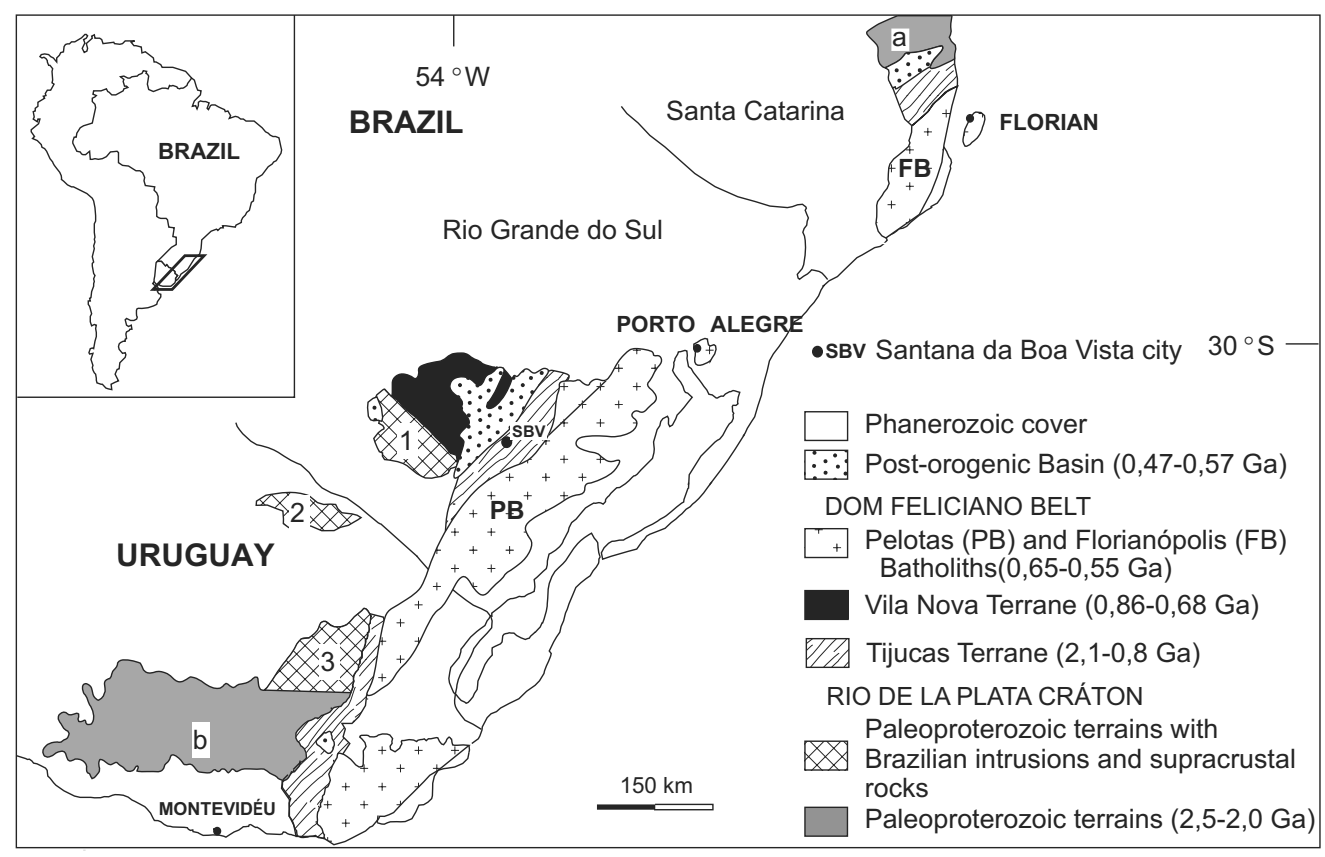

Fig. 1 - Main geotectonic units from southern Brazil and Uruguay. $a=$ Luis Alves Terrane, $b=$ Florida Terrane, 1 = Taquarembó Terrane, 2 = Rivera Terrane, 3 = Valentines Terrane. Modified from Chemale Jr. (2000).

tile shear zones which generate mylonites and modify the stratigraphic relations. Both units are part of the Tijucas Terrane, central portion of Dom Feliciano Belt in Rio Grande do Sul (Hartmann et al. 2007) (Fig. 1).

The studied orthogneisses show composite banding $\left(\mathrm{Sb}_{1}\right)$ which alternates trondhjemite and dioritic irregular bands with continuous and regular millimetersized banding attributed to metamorphic segregation. This banding is deformed by a low-angle event which generated $\mathrm{F}_{2}$ recumbent folding and $\mathrm{Sb}_{2}$ axial surface.

A third folding event is represented by normal and non-cylindrical folds oriented $\mathrm{N} 35-55^{\circ} \mathrm{E}$ with sub vertical axial surface. $F_{3}$ axes are deformed generating smooth and open asymmetric folds oriented $\mathrm{N} 20-40^{\circ} \mathrm{W}$ $\left(\mathrm{F}_{4}\right)$. The interaction of the last two events formed type 1 interference pattern which led to the Santana da Boa Vista structural dome (Machado et al., unpublished data). Porcher and Fernandes (1990) and Fernandes et al. (1992) interpreted the structural evolution of this complex and the shear zone development, as coeval, and related it to tectonic escape during the Brasiliano continental collision.

Dioritic gneiss and hornblendites form tabular bodies with thickness varying from $10 \mathrm{~cm}$ to $100 \mathrm{~m}$.
Their mineral parageneses record several metamorphic and deformational events that have affected them (R.P. Philipp and A.P. Viero, unpublished data). The older one is an orogenic regional metamorphism of medium to upper amphibolite facies, followed by a new metamorphic peak related with the intrusion of syntectonic Neoproterozoic granitoids. Granitoid emplacement is controlled by sub-horizontal ductile shear zones, which form a high-temperature mylonite fabric.

Later deformational phases of greenschist to lower-amphibolite facies are overprinted also in the supracrustal sequences of Porongos Group (Remus et al. 1990).

The Encantadas Complex gneisses are among the most important basement units of Paleoproterozoic age in the Sul-rio-grandense Shield. Recent geochemical, geochronological and structural researches indicate that this stratigraphic unit is NW-SE elongated and extends to southwest nearby Pinheiro Machado town (Philipp 1998) and to northeast towards the cities of Arroio dos Ratos (Leite et al. 1998) and Porto Alegre (Philipp and Campos 2004).

The main purpose of this paper is to characterize the geochemistry of the Encantadas Complex ortho- 


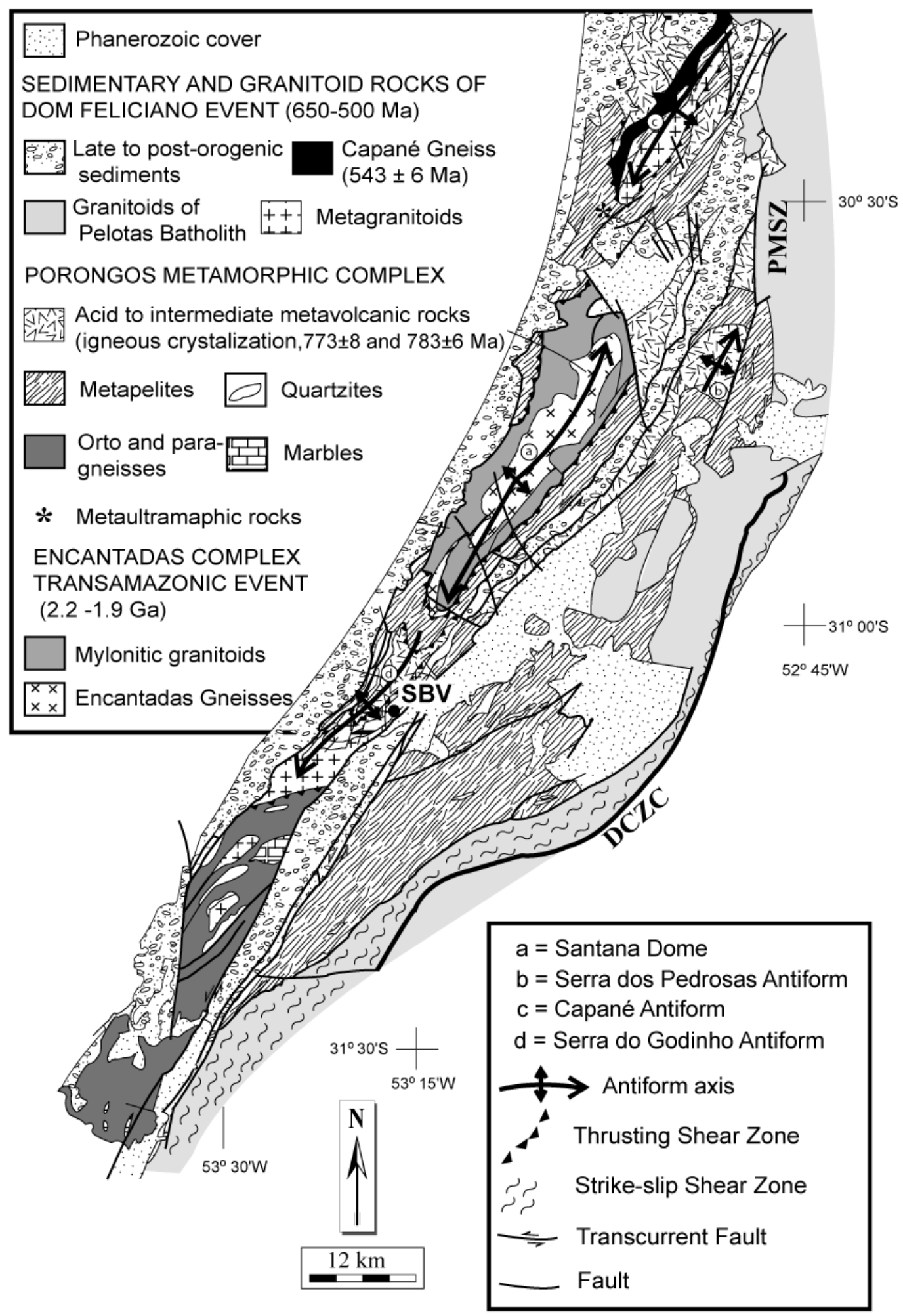

Fig. 2 - Geological map of the central region of Sul-Rio-Grandense Shield, with emphasis in the Santana da Boa Vista Dome and Encantadas Complex rocks. Modified from Chemale Jr. (2000). 
gneisses in order to discuss the probable sources and tectonic setting of their protoliths, as well as to investigate the evolution of metamorphism by studying microstructures and their relationship with tectonic foliations.

\section{PREVIOUS WORK}

Gneissic rocks in Santana da Boa Vista region were first described by Carvalho (1932) and Leinz and Pinagel (1945). Orthogneisses were considered medium-grade and included in the Encantadas Formation by Ribeiro et al. (1966). Based on field and structural data, Jost and Bitencourt (1980) recognized the gneissic sequence as forming a double plunging antiform structure and named it the Santana Dome.

Fernandes et al. (1992) defined the tectonic contact of gneissic rocks with metavolcanic and metasedimentary sequences of Porongos Metamorphic Complex as a low-angle ductile shear zone related to tectonic escape of the Brasiliano continental collision. Machado et al. (unpublished data) recognized part of the gneissic sequence as mylonite granitoids intruded by monzogranites and syenogranites.

Tabular amphibolite bodies were described as metamorphosed mafic dykes (Remus et al. 1990), in which Philipp and Viero (unpublished data) identified three different metamorphic events: (i) a thermal phase preceding the sub-horizontal shear zones, (ii) a second one related to mylonite formation in ductile shear zones, and (iii) a late phase associated with high-angle ductile and ductile-ruptile shear zones.

$\mathrm{U}-\mathrm{Pb}$ isotope determinations by SHRIMP in igneous zircon from the tonalitic gneisses yielded ages of 2, $263 \pm 18 \mathrm{Ma}$ and 2, $363 \pm 6 \mathrm{Ma}$, whilst metamorphic zircons show ages of 2, $045 \pm 10 \mathrm{Ma}$ and 2, $021 \pm 11 \mathrm{Ma}$ (Chemale Jr. 2000). A younger event of isotope resetting with age of $803 \pm 14$ Ma was identified by Chemale Jr. (2000). U-Pb data on zircon from metamorphosed magnesian metabasalts or pyroxenites were interpreted by Hartmann et al. (2003) as confirming the ages of igneous protoliths and allowed the determination of $\mathrm{M}_{1}$ and $\mathrm{M}_{2}$ regional metamorphism age as $1989 \pm 21 \mathrm{Ma}$ and $702 \pm 21 \mathrm{Ma}$, respectively. These authors related the $\mathrm{M}_{1}$ and $\mathrm{M}_{2}$ metamorphic events to the Encantadas and Camboriu orogenies of Transamazonic Cycle, and the Neoproterozoic one to the São Gabriel orogeny.

\section{GEOLOGICAL RELATIONS}

The stratigraphic relationship of Encantadas Complex units was based mostly on intrusion relationship. Tonalitic and trondhjemitic gneisses, as well as dioritic gneisses, are the oldest units followed by tabular intrusions of metagranodiorites and metamonzogranites with porphyritic and equigranular textures (Fig. 3). The youngest unit is constituted of tabular bodies of equigranular metaleucogranites with thickness of up to a few meters.

Two low-angle deformational events, $\mathrm{D}_{1}$ and $\mathrm{D}_{2}$, control the structural framework. $\mathrm{D}_{1}$ is observed mostly in tonalitic, trondhjemitic and dioritic gneiss and generates regular and discontinuous millimeter-sized banding, which is caused by metamorphic segregation.

$\mathrm{D}_{2}$ leads to recumbent folding $\left(\mathrm{F}_{2}\right)$ associated with axial surface foliation (Fig. 4). $\mathrm{D}_{3}$ is a transcurrent event, which refolds the previously formed structure and generates the $\mathrm{F}_{3}$ pattern, characterized by normal and cylindrical folding with $\mathrm{N} 35-55^{\circ} \mathrm{E}$ direction and sub vertical axial plane. The youngest deformation leads to the formation of asymmetric, open and smooth $\mathrm{F}_{4}$ folds, with axial planes oriented along $\mathrm{N} 20-40^{\circ} \mathrm{W}$.

Tonalitic gneisses occupy most of the studied area, whilst the trondhjemitic compositions predominate in the northern part of Santana Dome, where they form an elongated $\left(\mathrm{N} 10-20^{\circ} \mathrm{E}\right)$ body approximately $28 \mathrm{~km}$ long and $8 \mathrm{~km}$ wide (Fig. 3).

Dioritic gneisses are exposed along two linear trends oriented NE-SW mostly in the eastern part of Santana Dome (Fig. 3). The tabular or lensiform bodies are deformed and are concordant with the metamorphic banding of tonalitic and trondhjemitic gneisses. When occurring along ductile shear zones show banding and mylonite texture with amphibole porphyroclasts. The smaller lenses are 5 to $15 \mathrm{~cm}$ thick whilst the larger ones can reach up to $2 \mathrm{~m}$ of thickness. Mylonite deformation is more intensive in the smaller dioritic gneisses bodies. In the highly-deformed zones they occur as disrupted, very elongated bands with thickness ranging from 2 to $5 \mathrm{~cm}$ and length of 3 to $5 \mathrm{~m}$, which suggests high stretching rates.

The hornblendite bodies are less abundant and the major exposition show dimensions of $1.3 \mathrm{~km}$ and 150 $350 \mathrm{~m}$. The contacts are tectonic, and the ultramafic 


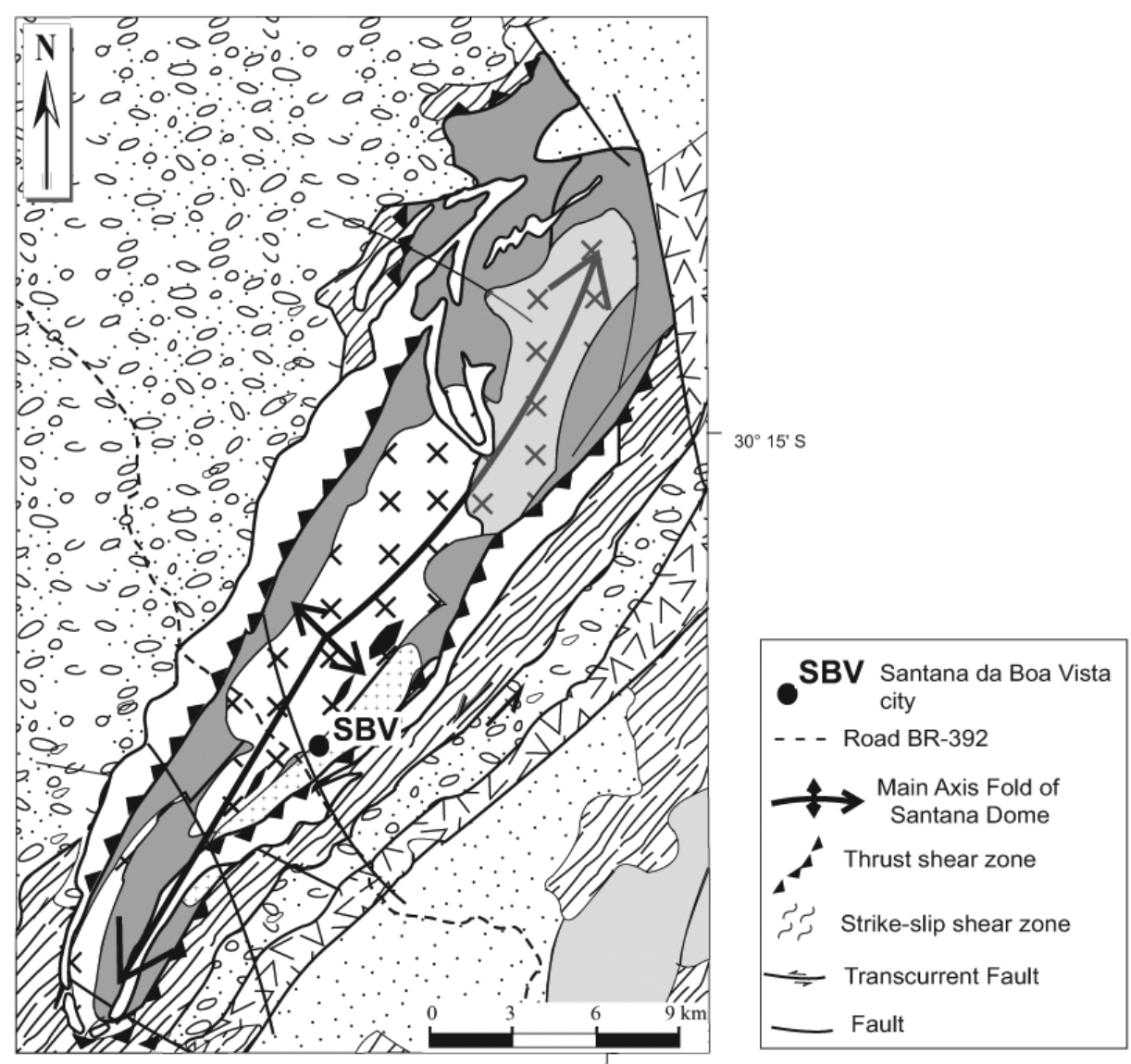

$52^{\circ} 30^{\prime} \mathrm{W}$

Phanerozoic cover

CAMAQUÃ BASIN $(0,58-0,47 \mathrm{Ga})$

Late- to post-orogenic sediments

DOM FELICIANO BELT $(0,65$ - 0,55 Ga)

Granitoid suites of Pelotas Batholith

PORONGOS COMPLEX $(0,77-0,78 \mathrm{Ga})$

选留 Acid to intermediate metavolcanics

Metapelites

Quartzites

\section{ENCANTADAS COMPLEX}

Equigranular Metaleucogranite

Porphyritic Metagranite

Encantadas Gneisses (2.3 -1.9 Ga)

$\hat{x}]$ Trondhjemitic gneisses

$x \times$
$x \times 1$ Tonalitic gneisses

Amphibolites and hornblendites

Fig. 3 - Geological map of Encantadas Complex.

body is involved by the low-angle mylonite foliation overprinted in the orthogneisses.

Porphyritic metagranodiorites and metamonzogranites are exposed as two aligned $\left(\mathrm{N} 10-15^{\circ} \mathrm{E}\right)$ bodies in the northern part of the dome, with about $24 \mathrm{~km}$ of length and 5 to $8 \mathrm{~km}$ wide. They show blastoporphyritic texture with 1 to $5 \mathrm{~cm}$ long K-feldspar porphyroclasts engulfed in a granoblastic and lepidoblastic groundmass made of quartz, feldspar and biotite. Although the fieldrelations of metagranitoids and orthogneisses are not exposed, the main foliation showed by metagranitoids is concordant with $\mathrm{Sb}_{1}$ banding and, is affected by $\mathrm{F}_{2}$ folding, suggesting that the emplacement of the metagranitoids is coeval with the $D_{1}$ event. 


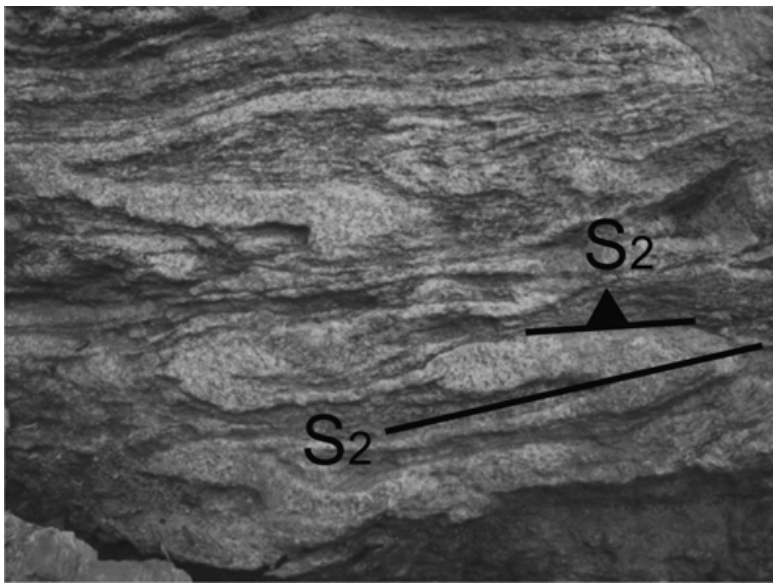

Fig. $4-F_{2}$ recumbent folding affecting the tonalitic gneiss banding and the leucogranite intrusions.

Metaleucogranites form tabular bodies with thicknesses varying from 0.05 to $10 \mathrm{~m}$. They are strongly deformed and show discordant intrusive contacts with the regional banding of the tonalitic and trondhjemitic gneisses.

Like the previously described metagranitoids, the metaleucogranites show a foliation concordant with $\mathrm{Sb}_{1}$ and they are affected by $F_{2}$ folding, which suggests that they are coeval with $\mathrm{D}_{1}$.

\section{PETROGRAPHY}

\section{TONALITIC GNEISS}

Tonalitic gneisses are dark grey with banded fabric, alternating millimeter-size layers of quartz and plagioclase with mafic ones containing biotite and amphibole. The felsic layers show interlobate granoblastic and polygonal heterogranular medium-grained textures $(0.2$ to $0.5 \mathrm{~mm}$ ) (Figs. 4 and 5). Mafic layers show lepidoblastic to nematoblastic textures and are also medium grained (0.2-0.8 mm). Along high-deformation $\mathrm{D}_{2}$ zones, the banding is more regular and thinner. Locally, the banded structure disappears and turns to homogeneous. Tonalitic gneisses have composition varying from tonalite to quartz diorite, with biotite, hornblende, allanite, apatite, zircon and Fe-Ti oxides (Fig. 6). Epidote and chlorite are secondary phases found mostly filling veins, replacing plagioclase and mafic minerals.

Calcic plagioclase occurs generally in the metamorphic groundmass and forms rare prismatic euhedral to

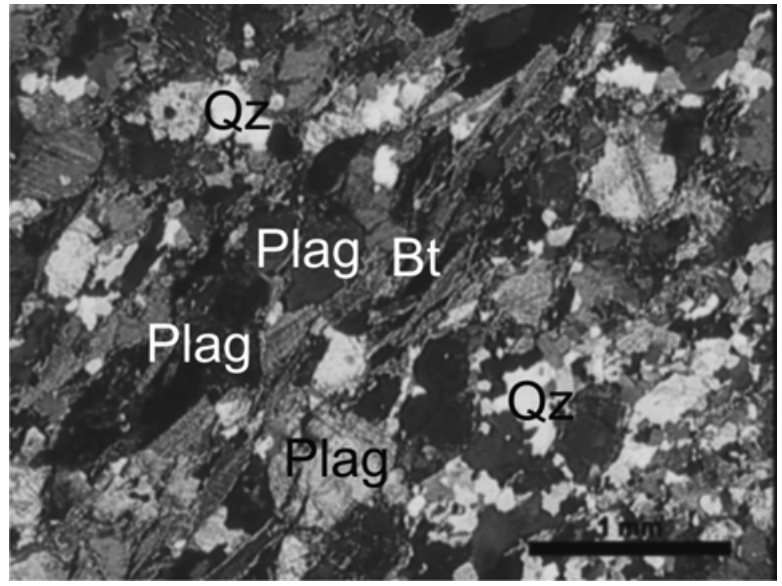

Fig. 5 - Incipient banding formed in tonalitic gneiss by alternation of mafic (biotite-rich) and felsic layers of quartz and plagioclase.

subhedral porphyroclasts with compositional zoning and size from 0.8 to $1.5 \mathrm{~mm}$. Intergranular contacts are sutured with metamorphic recrystallization along the borders. Metamorphic plagioclase crystals, 0.2 to $0.5 \mathrm{~mm}$ long, shows polygonal to equidimensional forms, with sharp and interlobate contacts. Quartz is generally recrystallized, but can, rarely, form elongated sub grains with strong undolose extinction and size from 0.5 to $1 \mathrm{~mm}$. Biotite is subhedral with greenish brown to reddish brown pleochroism. Hornblende forms subhedral grains with sizes from 0.3 to $0.8 \mathrm{~mm}$.

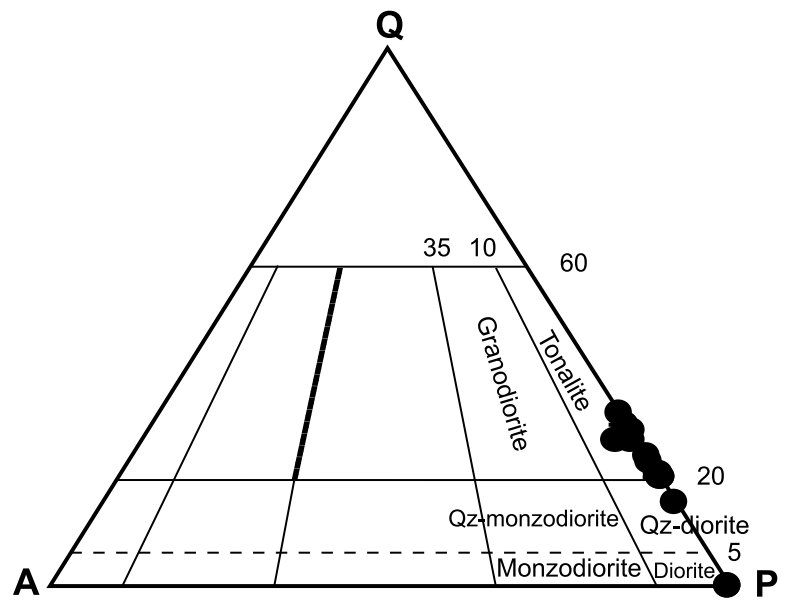

Fig. 6-Modal classification of Encantadas Complex orthogneisses in the QAP diagram (Streckeisen 1976).

The $\mathrm{Sb}_{1}$ banding containing the metamorphic mineral assemblage calcic plagioclase + quartz + biotite + horblende with the development of granoblastic 
polygonal textures characterizes medium-amphibolite facies conditions.

\section{TRONDHJEMITIC GNEISS}

Trondhjemitic gneisses are light grey and show incipient banding, alternating felsic with mafic layers where biotite is the major constituent. Their textures are similar to those observed in the tonalitic gneisses. In the highly deformed zones biotite is oriented, while quartz and plagioclase grains are recrystallized. Microcline, allanite, zircon, apatite and Fe-Ti oxides are common accessory phases. Chlorite, epidote and muscovite are secondary retrometamorphic phases.

Plagioclase is the major phase of trondhjemitic gneisses, sometimes occurring as euhedral to subhedral porphyroclasts with sizes from 0.4 to $1.0 \mathrm{~mm}$. The contacts are sutured with small-recrystallized grains along the porphyroclasts. Metamorphic plagioclase shows polygonal and equidimensional subidioblastic forms, straight to interlobate contacts, and sizes from 0.4 to $1.0 \mathrm{~mm}$. Quartz occurs as polygonal to equidimensional metamorphic grains, subidioblastic, with dimensions varying from 0.2 to $0.5 \mathrm{~mm}$. Microcline can occur as metamorphic polygonal or equidimensional grains, and more rarely as subhedral porphyroclasts with sizes from 2 to $3 \mathrm{~mm}$. The metamorphic grains show straight to interlobate contacts and sizes from 0.1 to $0.4 \mathrm{~mm}$.

Biotite occurs as interstitial grains in the felsic layers and as mineral aggregates in the mafic ones. Muscovite is rare and can replace plagioclase and $\mathrm{K}$-feldspar.

The metamorphic assemblage calcic plagioclase + quartz + biotite is characteristic of medium amphibolite facies conditions.

\section{DiORITIC GNEISS AND HORNBLENDITES}

The dioritic gneisses are foliated with orientation of plagioclase and hornblende grains and show medium to coarse grained nematoblastic texture. Heterogranular granoblastic interlobated textures are more localized and defined by plagioclase, diopside, opaque minerals and, sometimes, epidote and clinozoicite. The main mineralogical constituents are hornblende (42 to $65 \mathrm{vol} \%$ ), Narich plagioclase (38-58 vol\%), diopside (2 to $10 \mathrm{vol} \%$ ), titanite $(0.5 \mathrm{vol} \%)$ and opaque minerals ( 0.5 to $2.5 \mathrm{vol} \%)$. Along highly deformed zones there are mylonites with a banded structure alternating mafic and plagioclase layers with thickness from 0.2 to $2 \mathrm{~mm}$. Their texture is porphyroclastic with stretched amphibole and plagioclase grains with dimensions around 0.5 to $2 \mathrm{~mm}$.

The hornblendite shows massive structure and a coarse-grained (5-40 $\mathrm{mm}$ ) equigranular hypidiomorphic texture in some cases evolving to pegmatoid. Amphibole composes 90 to $95 \mathrm{vol} \%$ of the rock and is subhedral to euhedral with size varying from 0.5 to $4 \mathrm{~cm}$. Plagioclase (4 to 9 vol\%) occurs as subhedral to anhedral grains with dimensions from 5 to $10 \mathrm{~mm}$. Veins of granitic composition with thickness of 1 to $20 \mathrm{~mm}$ are locally concentrated. They show massive structure and equigranular hypidiomorphic texture.

\section{GEOCHEMISTRY AND PETROGENESIS}

Twelve samples from the Encantadas Gneisses were selected for major and trace elements determinations (Tables I, II and III). The determinations were performed in Activation Laboratories, Canada, by X-ray Fluorescence for major elements and by Inductively Coupled PlasmaMass Spectrometry (ICP-MS) for trace elements.

The studied orthogneisses show $\mathrm{SiO}_{2}$ contents ranging from $56.5 \%$ to $70 \mathrm{wt} \%$, corresponding to diorite, quartz diorites, tonalites and trondhjemites. $\mathrm{Al}_{2} \mathrm{O}_{3}$ contents are relatively high, 14 to $17 \mathrm{wt} \%$, like those of tonalitic associations of active continental margins (Arth 1979).

LIL elements show relatively high contents, particularly $\mathrm{Ba}$ and $\mathrm{Sr}$, whilst the $\mathrm{Zr}$ contents vary generally from 100 to 200 ppm (Fig. 7). Rb shows a wide dispersion in compositional diagrams and relatively low contents, which can be caused by metamorphic fluids. The decreasing $\mathrm{Rb}$ contents in more differentiated trondhjemites could be caused by biotite fractionation, however, the overprinted metamorphism probably modified the igneous patterns of highly mobile elements, like $\mathrm{Rb}$, Cs, U, and Th (Fig. 7). Sr contents (449-693 ppm) are relatively high, but commonly observed in Paleoproterozoic and Achaean tonalitic associations (Condie 2005) (Fig. 7). Zr, Nb, Ta, and Hf contents are relatively low as can be expected in tonalitic magmas produced by partial crustal melting of amphibolites or eclogites in Paleoproterozoic settings (Rapp et al. 1991, Martin 1993).

The studied gneisses have subalkaline character 
TABLE I

Chemical composition of Encantadas Complex gneisses - major elements.

\begin{tabular}{c|c|c|c|c|c|c|c|c|c|c|c|c}
\hline Sample & $\mathrm{SiO}_{2}$ & $\mathrm{Al}_{2} \mathrm{O}_{3}$ & $\mathrm{FeO}(\mathrm{t})$ & $\mathrm{MnO}$ & $\mathrm{MgO}$ & $\mathrm{CaO}$ & $\mathrm{Na}_{2} \mathrm{O}$ & $\mathrm{K}_{2} \mathrm{O}$ & $\mathrm{TiO}_{2}$ & $\mathrm{P}_{2} \mathrm{O}_{5}$ & LOI & Total \\
\hline $2 \mathrm{~A}$ & 65.16 & 15.81 & 4.73 & 0.072 & 2.05 & 4.22 & 4.08 & 1.93 & 0.477 & 0.23 & 0.74 & 99.5 \\
\hline $4 \mathrm{~A}$ & 63.59 & 15.65 & 6.17 & 0.112 & 2.1 & 4.63 & 3.64 & 2.41 & 0.573 & 0.23 & 0.61 & 99.72 \\
\hline $5 \mathrm{~A}$ & 67.91 & 15.81 & 3.24 & 0.036 & 1.2 & 3.31 & 3.79 & 2.91 & 0.481 & 0.11 & 0.58 & 99.37 \\
\hline $6 \mathrm{~A}$ & 5.47 & 16.56 & 8.14 & 0.122 & 4.21 & 6.56 & 3.44 & 2.65 & 0.721 & 0.17 & 0.77 & 99.82 \\
\hline $7 \mathrm{~A}$ & 64.86 & 16.77 & 4.27 & 0.062 & 1.92 & 3.37 & 4.91 & 1.96 & 0.469 & 0.27 & 0.73 & 99.6 \\
\hline $11 \mathrm{~B}$ & 56.74 & 14.91 & 9.8 & 0.21 & 4.38 & 6.65 & 3.4 & 1.76 & 0.765 & 0.21 & 0.86 & 99.68 \\
\hline 13 & 70.03 & 15.58 & 2.4 & 0.035 & 1.15 & 3.72 & 4.24 & 1.4 & 0.265 & 0.09 & 0.64 & 99.56 \\
\hline $14 \mathrm{C}$ & 69.22 & 15.51 & 3.05 & 0.046 & 1.35 & 3.55 & 4.14 & 2.08 & 0.338 & 0.16 & 0.51 & 99.96 \\
\hline 15 & 66.35 & 16.81 & 3.28 & 0.038 & 1.94 & 3.66 & 3.85 & 2.19 & 0.346 & 0.11 & 0.88 & 99.46 \\
\hline $16 \mathrm{~A}$ & 58.74 & 16 & 7.73 & 0.111 & 3.94 & 4.78 & 2.25 & 3.3 & 0.713 & 0.26 & 1.85 & 99.67 \\
\hline $19 \mathrm{~A}$ & 67.09 & 14.19 & 5.47 & 0.054 & 1.74 & 2.53 & 3.41 & 3.13 & 0.789 & 0.31 & 0.79 & 99.52 \\
\hline 20 & 68.7 & 15.64 & 3.25 & 0.045 & 1.29 & 2.98 & 4.31 & 2.33 & 0.368 & 0.15 & 0.9 & 99.95 \\
\hline
\end{tabular}

TABLE II

Chemical composition of Encantadas Complex gneisses - trace elements.

\begin{tabular}{c|c|c|c|c|c|c|c|c|c|c|c|c|c|c|c}
\hline Sample & $\mathrm{Sc}$ & $\mathrm{Be}$ & $\mathrm{V}$ & $\mathrm{Ba}$ & $\mathrm{Sr}$ & $\mathrm{Y}$ & $\mathrm{Zr}$ & $\mathrm{Ga}$ & $\mathrm{Rb}$ & $\mathrm{Nb}$ & $\mathrm{Cs}$ & $\mathrm{Hf}$ & $\mathrm{Ta}$ & $\mathrm{Th}$ & $\mathrm{U}$ \\
\hline $2 \mathrm{~A}$ & 8 & 2 & 70 & 761 & 610 & 13 & 121 & 14 & 48 & 5 & 1.1 & 3.2 & 0.2 & 3.4 & 0.4 \\
\hline 4A & 14 & 2 & 95 & 869 & 589 & 25 & 175 & 15 & 45 & 11 & $<0.5$ & 4.6 & 0.9 & 12.8 & 0.7 \\
\hline $5 \mathrm{~A}$ & 2 & 2 & 34 & 913 & 449 & 6 & 105 & 14 & 28 & 8 & 0.6 & 2.8 & 0.3 & 6.1 & 0.2 \\
\hline $6 \mathrm{~A}$ & 15 & 1 & 105 & 1322 & 515 & 28 & 113 & 16 & 52 & 10 & 0.8 & 3.2 & 0.7 & 2.8 & 0.5 \\
\hline $7 \mathrm{~A}$ & 7 & 3 & 58 & 811 & 693 & 11 & 228 & 18 & 67 & 8 & 2 & 503 & 0.4 & 9.1 & 0.6 \\
\hline $11 \mathrm{~B}$ & 25 & 2 & 178 & 419 & 459 & 39 & 69 & 16 & 36 & 10 & $<0.5$ & 2.3 & 0.5 & 0.8 & 0.1 \\
13 & 3 & $<1$ & 23 & 455 & 469 & 3 & 107 & 13 & 31 & 3 & 0.9 & 3.1 & 0.1 & 6.7 & 0.2 \\
\hline $14 \mathrm{C}$ & 5 & 2 & 45 & 1276 & 626 & 7 & 118 & 13 & 40 & 4 & 0.8 & 3.1 & 0.2 & 9.5 & 0.4 \\
\hline 15 & 6 & $<1$ & 38 & 408 & 457 & 5 & 97 & 15 & 31 & 2 & 0.6 & 2.6 & 0.1 & 0.5 & 0.1 \\
\hline $16 \mathrm{~A}$ & 20 & 1 & 139 & 621 & 636 & 20 & 174 & 14 & 60 & 7 & 1.3 & 4.7 & 0.4 & 7.2 & 0.3 \\
\hline $19 \mathrm{~A}$ & 12 & 2 & 60 & 1480 & 540 & 24 & 358 & 16 & 64 & 10 & 1.4 & 8.5 & 0.4 & 12 & 0.6 \\
\hline 20 & 4 & 1 & 37 & 1054 & 543 & 6 & 124 & 14 & 35 & 4 & $<0.5$ & 3.4 & 0.2 & 9.1 & 0.3 \\
\hline
\end{tabular}

TABLE III

Chemical composition of Encantadas Complex gneisses - rare earth elements.

\begin{tabular}{c|c|c|c|c|c|c|c|c|c|c|c|c|c|c}
\hline Sample & $\mathrm{La}$ & $\mathrm{Ce}$ & $\mathrm{Pr}$ & $\mathrm{Nd}$ & $\mathrm{Sm}$ & $\mathrm{Eu}$ & $\mathrm{Gd}$ & $\mathrm{Tb}$ & $\mathrm{Dy}$ & $\mathrm{Ho}$ & $\mathrm{Er}$ & $\mathrm{Tm}$ & $\mathrm{Yb}$ & $\mathrm{Lu}$ \\
\hline 2A & 37.7 & 72.6 & 8.5 & 30 & 5 & 1.71 & 3.9 & 0.5 & 2.2 & 0.4 & 1.1 & 0.15 & 1 & 0.15 \\
\hline 4A & 41 & 77 & 8.89 & 31.3 & 5.8 & 1.54 & 5.3 & 0.7 & 4.1 & 0.8 & 2.4 & 0.38 & 2.5 & 0.35 \\
\hline 5A & 30 & 55.4 & 5.83 & 18.6 & 2.6 & 1.02 & 2 & 0.2 & 1 & 0.2 & 0.5 & 0.07 & 0.5 & 0.07 \\
\hline 6A & 29.3 & 66.3 & 8.68 & 32.1 & 6.4 & 1.71 & 5.8 & 0.9 & 4.8 & 0.9 & 2.7 & 0.4 & 2.6 & 0.38 \\
\hline 7A & 32.7 & 68.2 & 8.03 & 27.3 & 4.5 & 1.16 & 3.4 & 0.4 & 2 & 0.4 & 1 & 0.14 & 0.8 & 0.12 \\
\hline $11 \mathrm{~B}$ & 17.2 & 45.5 & 6.88 & 30.8 & 8.2 & 2.27 & 7.6 & 1.2 & 7 & 1.4 & 4.1 & 0.59 & 3.7 & 0.54 \\
\hline 13 & 28.3 & 54.7 & 5.92 & 18.6 & 2.6 & 0.83 & 1.8 & 0.2 & 0.7 & 0.1 & 0.4 & $<0.05$ & 0.3 & 0.05 \\
\hline 14C & 31.6 & 60.7 & 6.82 & 22.5 & 3.2 & 1.28 & 2.3 & 0.3 & 1.2 & 0.2 & 0.5 & 0.08 & 0.6 & 0.07 \\
\hline 15 & 8.3 & 16.4 & 2.02 & 7.5 & 1.6 & 0.62 & 1.4 & 0.2 & 1 & 0.2 & 0.5 & 0.07 & 0.4 & 0.06 \\
\hline 16A & 32.9 & 69.4 & 8.47 & 31.4 & 6 & 1.47 & 5 & 0.7 & 3.7 & 0.7 & 2 & 0.29 & 1.8 & 0.25 \\
\hline 19A & 109 & 215 & 25.2 & 84.3 & 12.1 & 2.61 & 8.9 & 1 & 4.7 & 0.8 & 2.2 & 0.32 & 1.9 & 0.26 \\
\hline 20 & 30.6 & 59.3 & 6.71 & 21.8 & 3.2 & 1.03 & 2.3 & 0.2 & 1.1 & 0.2 & 0.5 & 0.07 & 0.4 & 0.07 \\
\hline
\end{tabular}



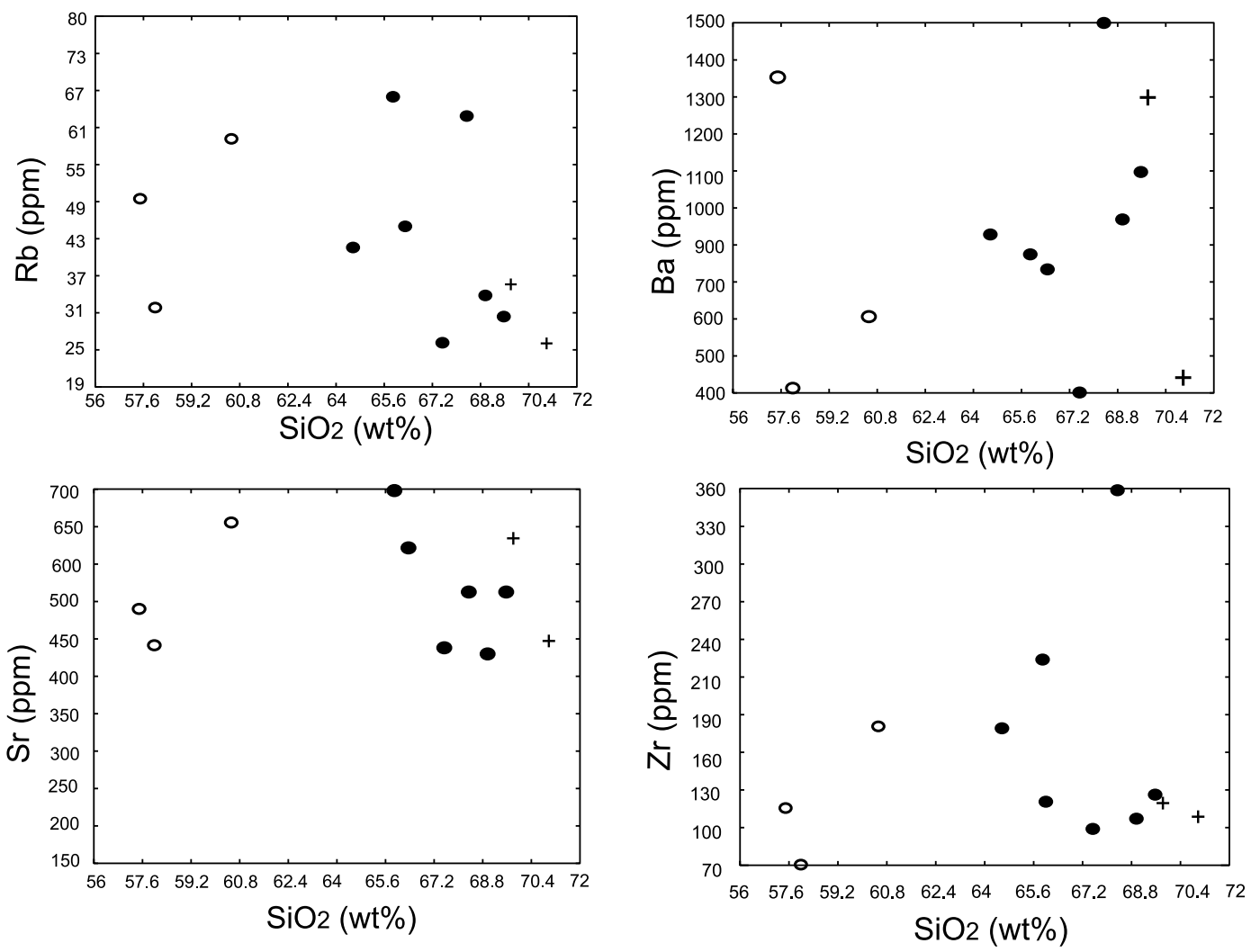

Legend: $\bigcirc$ Dioritic gneiss

Tonalitic gneiss

+ Trondhjemitic gneiss

Fig. 7 - Variation diagrams for $\mathrm{Rb}, \mathrm{Ba}, \mathrm{Sr}$ and $\mathrm{Zr}$ againts $\mathrm{SiO}_{2}$ as the differentiation index, for the orthogneisses from Encantadas Complex.

defined by relatively low alkali content in the TAS diagram and are metaluminous to slightly peraluminous (Figs. 8 and 9). The non-tholeiitic affinity of these rocks is indicated by the AFM diagram (Fig. 10) and by the $\left(\mathrm{Fe}_{\text {tot }}+\mathrm{Ti}\right)-\mathrm{Al}-\mathrm{Mg}$ classification diagram (Jensen 1976) (Fig. 11). These diagrams are used based on the assumption that most samples represent crystallized magmatic liquids; those which are interpreted as cumulates were excluded. The $\mathrm{K}_{2} \mathrm{O}$ contents in relation to $\mathrm{SiO}_{2}$ classify them as medium-K subalkaline rocks as proposed by Le Maitre (1989) (Fig. 12).

The tonalitic and trondhjemitic gneisses of Encantadas Complex are compositionally classified as a TTG association, following the concept adopted by Condie (2005), since they show $\mathrm{Al}_{2} \mathrm{O}_{3}$ contents at $70 \mathrm{wt} \% \mathrm{SiO}_{2}$ larger than $15 \mathrm{wt} \%, \mathrm{Mg} \#\left[\left(100 \mathrm{MgO} /\left(\mathrm{FeO}_{\mathrm{T}}+\mathrm{MgO}\right)\right]\right.$ varying from 20 to $40, \mathrm{Sr}>300 \mathrm{ppm}, \mathrm{Y}<20 \mathrm{ppm}$, $\mathrm{Yb}<1.8 \mathrm{ppm}$ and $\mathrm{Nb}<10 \mathrm{ppm}$. The $\mathrm{Y}$ contents are in fact lower than $10 \mathrm{ppm}$ at $70 \mathrm{wt} \% \mathrm{SiO}_{2}$, which is very typical of Achaean tonalites, whilst the Proterozoic ones have contents around 15, as referred by Condie (2005).

$\mathrm{K}_{2} \mathrm{O} / \mathrm{Na}_{2} \mathrm{O}$ ratios are around 0.55 in the Encantadas tonalites which are comparable to those of tonalites of Achaean or Proterozoic ages, whilst those of Proterozoic age have higher ratios close to 0.68 (Condie 2005).

According to the discriminating parameters suggested by Condie (2005) for TTG, adakites and their differentiated products, and sanukitoids (Lopez et al. 2005), the tonalitic association that originated the Encantadas gneisses is a TTG association typical of Achaean or Proterozoic ages.

REE patterns normalized against chondrite values show decreasing of HREE in the more differentiated rocks (Fig. 12). The patterns are approximately parallel, suggesting that dioritic and tonalitic rocks can be co-magmatic or cogenetic. Dioritic gneisses show $\mathrm{La}_{\mathrm{N}}$ values close to 100 and $\mathrm{Yb}_{\mathrm{N}}$ close to 10 , whilst tonalites and trondhjemites have $\mathrm{La}_{\mathrm{N}}$ around 100 and $\mathrm{Yb}_{\mathrm{N}}$ vary- 


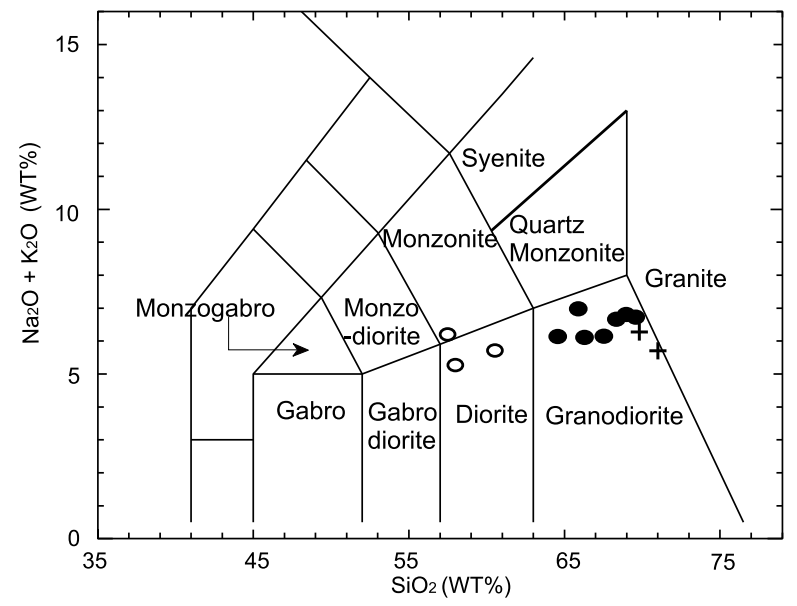

Fig. 8 - TAS diagram. Symbols as in Figure 7.

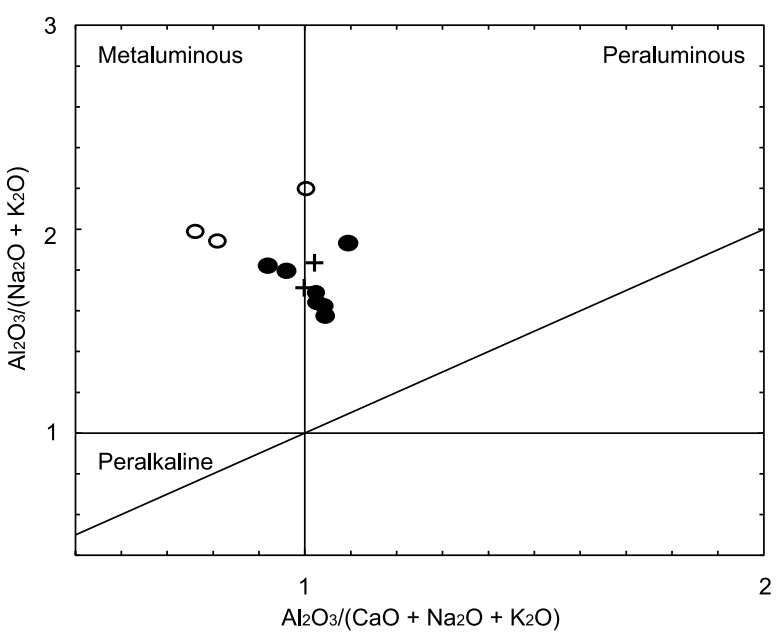

Fig. 9 - SHAND's classification. Symbols as in Figure 7.

ing from 4 to 2, which leads to $\mathrm{La}_{\mathrm{N}} / \mathrm{Yb}_{\mathrm{N}}$ values around 25 to 50. REE patterns of Encantadas tonalitic gneisses are similar to those referred by Rapp et al. (1991) and Condie (2005) as typical of high-pressure melts equilibrated with eclogitic residue like Achaean tonalites. The lack of negative Eu-anomalies indicates low abundance of plagioclase as a fractionated or residual phase. The highly fractionated REE patterns require the presence of garnet in the residuum or as a fractionated phase (Martin 1993).

Spidergrams of gneisses from Encantadas Complex samples normalized against primitive mantle values show enrichment of LIL and LREE elements and sharp negative anomalies of $\mathrm{Nb}, \mathrm{Ti}$, and $\mathrm{U}$, like continental-arc magmatism (Fig. 14).

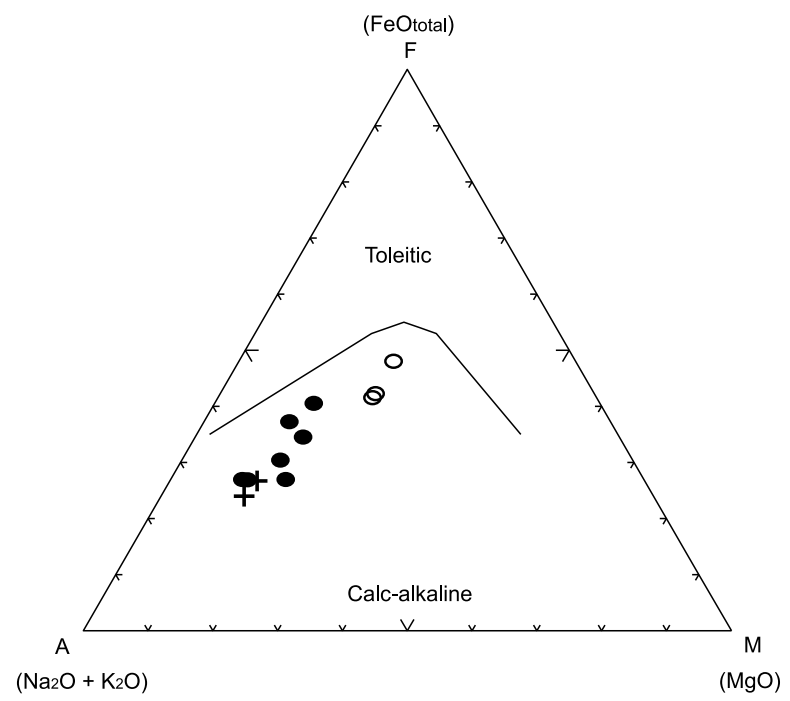

Fig. 10 - AFM diagram (Irvine and Baragar 1971) for the Encantadas Complex orthogneisses. Symbols as in Figure 7.

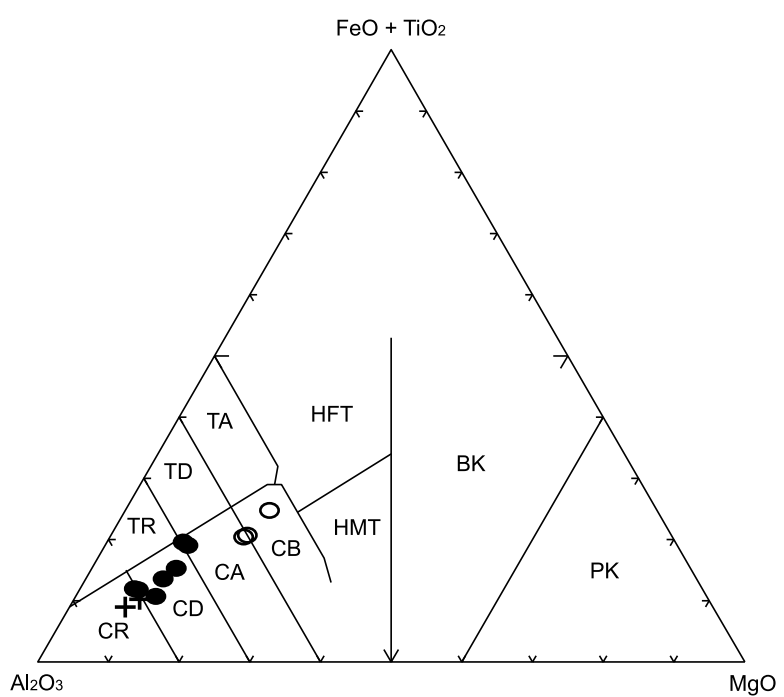

Fig. 11 - Encantadas Complex orthogneisses plot in the Jensen's diagram (1976). Symbols as in Figure 7.

\section{Magmatic Sources And Settings}

Tonalitic and trondhjemitic Encantadas gneisses show patterns in the diagrams suggested by Pearce et al. (1984) with strong negative anomalies for $\mathrm{U}, \mathrm{Rb}, \mathrm{Nb}$, and $\mathrm{Ti}$. The two former are probably explained by the high mobility of both elements during metamorphism, whilst $\mathrm{Nb}$ and $\mathrm{Ti}$ anomalies indicate that these magmas were produced from mantle sources modified by metasomatism associated to lithosphere subduction (Thompson et al. 1984). 


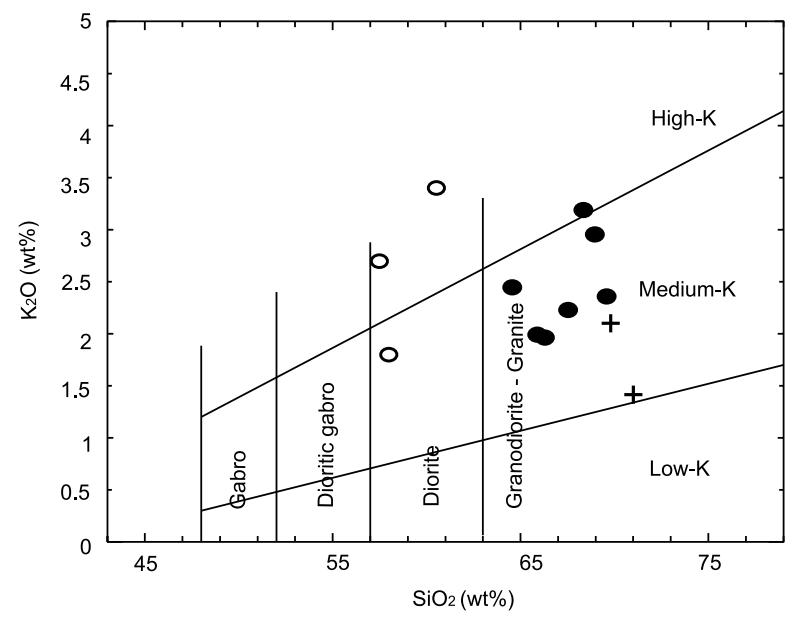

Fig. 12 - Encantadas Complex orthogneisses in the $\mathrm{K}_{2} \mathrm{O} \times \mathrm{SiO}_{2}$ diagram (Le Maitre 1989). Symbols as in Figure 7.

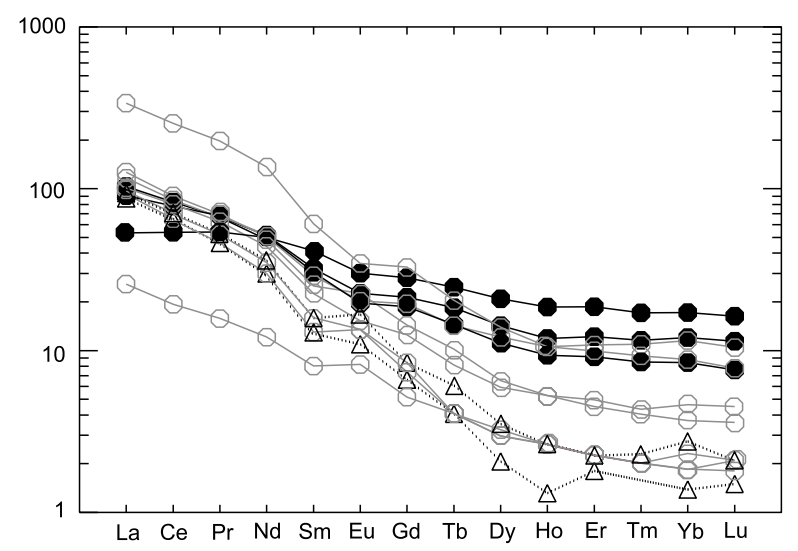

Fig. 13 - Encantadas Complex orthogneiss REE patterns normalized against chondritic values.

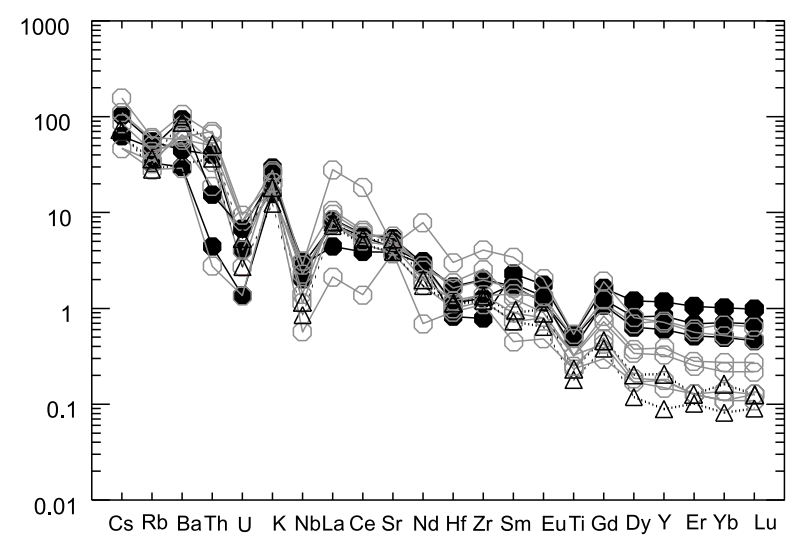

Fig. 14 - Encantadas Complex gneiss spiderdiagrams for incompatible elements. Legend: • Dioritic gneiss; O Tonalitic gneiss; $\Delta$ Trondhjemitic gneiss.
The major element parameters R1-R2 (Batchelor and Bowden 1985) and the $\mathrm{Y}$ versus $\mathrm{Nb}$ and $\mathrm{Rb}$ versus ( $\mathrm{Y}$ $+\mathrm{Nb}$ ) diagrams (Pearce et al. 1984, Pearce 1996) points to the similarity of the studied rocks with magmatic arc associations (Figs. 15 and 16).

Condie (2005) admits that "adakites are probably slab melts, whilst high-Al TTG may be produced by partial melting of the lower crust in arc systems or in the root zones of oceanic plateaus". High-Al TTG, that means tonalitic rocks with $\mathrm{Al}_{2} \mathrm{O}_{3}>15 \mathrm{wt} \%$ (Rapp et al. 1991, Condie 2005), from Encantadas Gneisses could be produced by partial melting of amphibolites or eclogites under high pressures (depths from 40 to $80 \mathrm{~km}$ ), since their $\mathrm{Sr}$ and HREE contents indicate the presence of garnet and the lack of plagioclase in the residuum or fractionation of hornblende. The relatively high $\mathrm{Nb} / \mathrm{Ta}$ ratios (2025) of Encantadas tonalitic gneisses are comparable to those of tonalite derived from less differentiated mantle melts or high-pressure melts equilibrated with eclogitic residue (Condie 2005).

TTG associations can also be formed by differentiation of komatiitic or adakitic mantle-derived magmas. The available data do not allow opting between these two possible origins for Encantadas Complex magmas. As far as the tectonic setting is concerned, the root zones of oceanic plateaus are ruled out for the Encantadas Complex, since there is no evidence of oceanic magmatic associations in this context. An arc continental system seems an adequate model for the available data.

\section{CONCLUSIONS}

Dioritic, tonalitic and trondhjemitic protoliths of Encantadas Gneisses are typical high-AL TTG associations according to the criteria suggested by Condie (2005), which are commonly found in active continental margins.

Most compositional parameters and particularly the association of mafic and tonalitic rocks are consistent with a common evolution from less differentiated magmas, probably through fractional crystallization, since hornblendites and dioritic gneisses that occur in the same association could represent cumulates. However, the relationship of tonalitic and dioritic rocks should be discussed with a better geochemical and isotopic data set, not yet available. This Paleoproterozoic magmatism is 


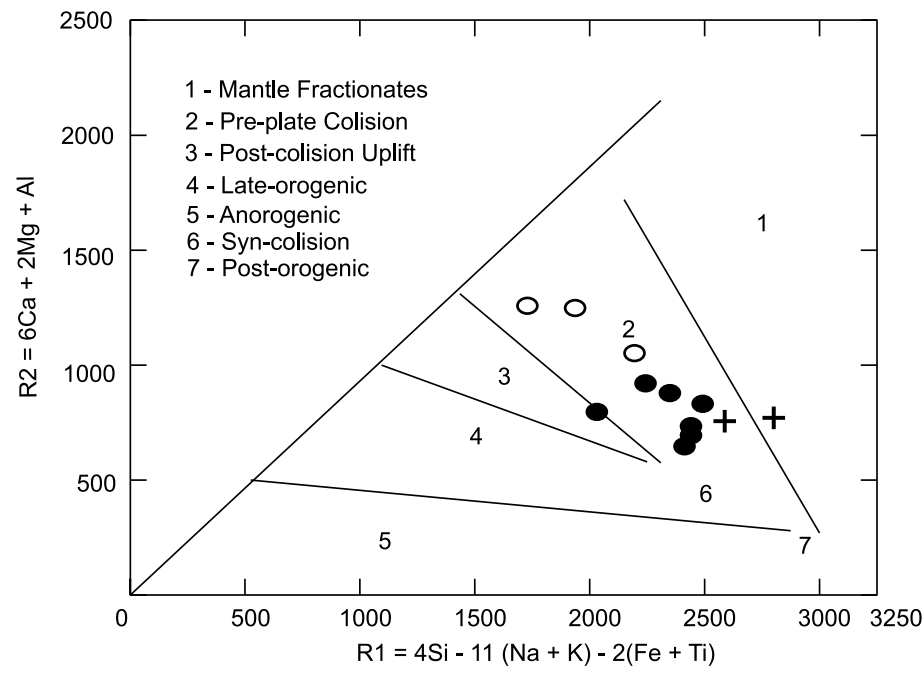

Legenda: $\bigcirc$ Dioritic gneiss Tonalitic gneiss + Trondhjemitic gneiss

Fig. 15 - Plot R1-R2 (Debon and Le Fort 1983) for the Encantadas Complex orthogneissses.

metaluminous to slightly peraluminous and can be related to a medium-K calc-alkaline magmatic series.

Trace and major element patterns of tonalitic gneisses, such as $\mathrm{La}_{\mathrm{N}} / \mathrm{Yb}_{\mathrm{N}}$ and $\mathrm{K}_{2} \mathrm{O} / \mathrm{Na}_{2} \mathrm{O}$ ratios and $\mathrm{Y}, \mathrm{Yb}$ and $\mathrm{Lu}$ contents, are very similar to Archaean tonalites as discussed by Condie (2005), which is coherent with the Paleoproterozoic ages found by U/Th determinations in zircons (Chemale Jr. 2000) and Rb-Sr in whole rocks samples (Soliani Jr. 1986).

The compositional features of Encantadas tonalitic gneisses are usually described in rocks formed by partial melting of mafic rocks under high-pressure conditions, leaving an eclogitic residue (Rapp et al. 1991, Condie 2005). However, the presence of abundant dioritic rocks and hornblendites, which may represent cumulates, associated to tonalitic and trondhjemitic Encantadas gneisses suggest that tonalitic magmas could be formed by hornblende-controlled fractionation of hydrous basaltic magmas as discussed by Rapp et al. (1991). The medium to low-K calc-alkaline affinity, as well as the high LREE/Nb ratios, and the patterns illustrated in Pearce et al. (1984) diagrams are consistent with continental arc magmatism.

The geochemical parameters, as well as the tectonic and geochronological features, of dioritic, tonalitic and trondhjemitic gneisses from Encantadas Complex are consistent with a continental-arc magmatism of $\mathrm{Pa}$ leoproterozoic age. So that, the Paleoproterozoic age in southernmost Brazil was a period of vertical accretion, with magmas derived from a mantle metasomatized by subduction-related fluids.

\section{ACKNOWLEDGMENTS}

We are indebted to the Instituto de Geociências of UFRGS for support for field work and, to prof. Luis Fernando De Ros for making available the microscope for digital photomicrographs. This research was supported by Conselho Nacional de Desenvolvimento Científico e Tecnológico (CNPq) Project Programa de Apoio a Núcleos de Excelência (PRONEX) no. 04/0825-3, project no. 309232/2003-1, and by CNPq grants to the first and third authors.

\section{RESUMO}

O Complexo Encantadas é constituído por gnaisses tonalíticos, trondhjemíticos e dioríticos com presença subordinada de hornblenditos. Os elementos maiores e traços indicam uma composição metaluminosa a fracamente peraluminosa relacionada às séries cálcico-alcalinas médio-K. Os parâmetros composicionais são consistentes com uma evolução associada provavelmente a cristalização fracionada a partir de magmas menos diferenciados. Os ortognaisses mostram razões $\mathrm{La}_{\mathrm{N}} / \mathrm{Yb}_{\mathrm{N}}$ variando entre 10 até $50, \mathrm{~K}_{2} \mathrm{O} / \mathrm{Na}_{2} \mathrm{O}$ entre 1,1 e 3,0, com conteúdos de Y entre 3 e 39, Yb entre 0,3 e 3,7 e Lu entre 0,06 e 0,54 . Estas feições são similares às descritas em tonalitos 

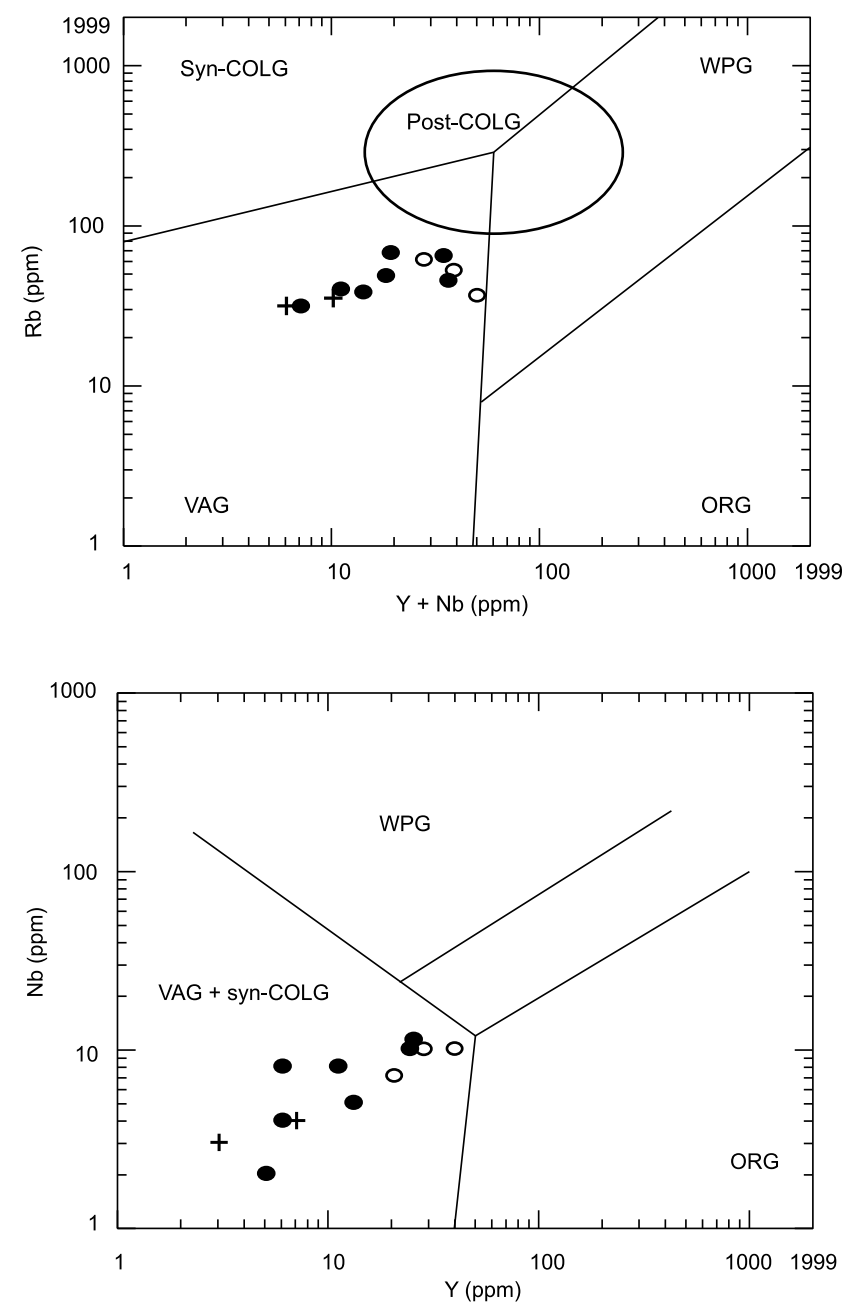

Legend: $\bigcirc$ Dioritic gneiss

Tonalitic gneiss

$+\quad$ Trondhjemitic gneiss

Fig. 16 - Plots of gneisses from Encantadas Complex in the $\mathrm{Rb} \times \mathrm{Y}+\mathrm{Nb}$ and $\mathrm{Nb} \times \mathrm{Y}$ (Pearce et al. 1984, Pearce 1996) diagrams.

arqueanos, usualmente atribuídas à fusão parcial de seqüências máficas sob condições de alta pressão deixando um resíduo eclogítico. A presença de dioritos e hornblenditos, associados aos gnaisses tonalíticos e trondhjemíticos sugere, por outro lado, que os mesmos podem representar rochas com uma evolução comum, geradas provavelmente por fracionamento de hornblenda a partir de magmas básicos hidratados. Os tonalitos apresentam idade U-PbSHRIMP em zircão de 2, $263 \pm 6 \mathrm{Ma}$ para a cristalização e $2,045 \pm 10$ Ma para o metamorfismo. Os parâmetros geoquímicos, tectônicos e geocronológicos são consistentes com magmas derivados de manto metassomatizado por fluídos relacionados com subducção oceânica em uma margem continental ativa.

Palavras-chave: arco magmático, evolução crustal, gnaisses Encantadas, Paleoproterozóico, Petrologia, TTG.

\section{REFERENCES}

ARTH JG. 1979. Some trace elements in trondhjemites - their implications to magma genesis and paleotectonic settings. In: BARKER F (Ed.), Trondhjemites, Dacites and related rocks. New York: Elsevier, New York, USA, p. 123-132.

BATCHElor RA AND Bowden P. 1985. Petrogenetic interpretation of granitoid rock series using multicationic parameters. Chem Geol 48: 43-55.

Carvalho PF. 1932. Reconhecimento geológico do Rio Grande do Sul. Rio de Janeiro, Bol Inst Geol Min Bras 66: $1-72$.

Chemale JR. F. 2000. Evolução Geológica do Escudo Sulrio-grandense. In: Holz M ET AL. (Eds), Geologia do Rio Grande do Sul, Porto Alegre: CIGO, Porto Alegre, Brasil, p. 13-52. 
CONDIE KC. 2005. TTGs and adakites: are they both slab melts? Lithos 80: 33-44.

DEBON F AND LE FORT P. 1983. A chemical-mineralogical classification of common plutonic rocks and associations. Trans Roy Soc Edin 73: 135-149.

Fernandes LA, Tommasi A And Porcher CC. 1992. Deformation patterns in the Southern Brazilian branch of the Dom Feliciano Belt: a reappraisal. J South Am Earth Sci 5: 77-96.

Hartmann LA, Santos JOS, Leite JAD, Porcher CC, McNaughton I and Neal J. 2003. Metamorphic evolution and U-Pb zircon SHRIMP geochronology of the Belizário ultramafic amphibolite, Encantadas Complex, southernmost Brazil. An Acad Bras Cienc 75: 393-403.

Hartmann LA, Chemale JR. F AND Philipp RP. 2007. Evolução Geotectônica do Rio Grande do Sul no PréCambriano. In: Frantz JC ET AL. (Eds), 50 anos de Geologia no Rio Grande do Sul, Porto Alegre: Comunicação e Identidade, Porto Alegre, RS, Brasil, p. 97-123.

IRVINE TN AND BARAGAR WRA. 1971. A guide to the chemical classification of the common volcanic rocks. Can J Earth Sci 8: 523-548.

JENSEN LS. 1976. A new cationic plot for classifying subalkalic volcanic rocks. Ontario Div. Mines, Miscel Paper 6: $1-22$.

Jost H AND Bitencourt MF. 1980. Estratigrafia e tectônica de uma fração da Faixa de Dobramentos Tijucas no Rio Grande do Sul. Acta Geol Leop 11(7): 27-59.

Leite JAD, Hartmann LA, McNaughton NJ AND Chemale JR. F. 1998. SHRIMP U/Pb zircon geochronology of Neoproterozoic juvenile and crustal-reworked terranes in southernmost Brazil. Inter Geol Rev 40: 688705 .

Le Maitre RW. 1989. A classification of igneous rocks and glossary of terms. Oxford: Blackwell, 193 p.

LeinZ V AND Pinagel H. 1945. Estanho e tungstênio no Rio Grande do Sul. Bol Div Fom Prod Min 70: 1-80.

Lopez S, Castro A and Garcia-Casco A. 2005. Production of granodiorite melt by interaction between hydrous mafic magma and tonalitic crust. Experimental constraints and implications for the generation of Archaean TTG complexes. Lithos 79: 229-250.
MARTIN H. 1993. The mechanisms of petrogenesis of the Archean continental crust- comparison with modern processes. Lithos 30: 373-388.

PEARCE JA. 1996. Sources and settings of granitic rocks. Episodes 19(4): 120-125.

Pearce JA, Harris NBW and Tindle AG. 1984. Trace element discrimination diagrams for the tectonic interpretation of granitic rocks. J Petrol 25: 956-983.

PhILIPP RP. 1998. A Evolução Geológica e Tectônica do Batólito Pelotas no Rio Grande do Sul. Universidade de São Paulo, SP. Tese de Doutorado, 255 p.

Philipp RP AND CAMPOS RS. 2004. Geologia, petrografia e litogeoquímica dos Gnaisses Porto Alegre, RS, Brasil: implicações geotectônicas. Pesq Geoc 31(2): 79-94.

Porcher CC AND Fernandes LAD. 1990. Relações Embasamento/"Cobertura" na porção Ocidental do Cinturão Dom Feliciano: um esboço estrutural. Pesq 17(1-2): 72 84.

Rapp RP, Watson EB AND Miller CF. 1991. Partial melting of amphibolite/eclogite and the origin of Archean trondhjemites and tonalites. Precam Res 51: 1-25.

REMUS MVD, PhILIPP RP, FACCINI UF AND JUNGES SL. 1990. Contribuição ao estudo geológico-estrutural dos Gnaisses Encantadas e das relações com as supracrustais Porongos na região de Santana da Boa Vista-RS. In: CONGresso Brasileiro De Geologia, 36, Natal, RN, Brasil, SBG 1: 2358-2370.

Ribeiro M, Bocchi PA, Figueiredo $\mathrm{F}^{\circ}$ PM ANd TesSARI RI. 1966. Geologia da quadrícula de Caçapava do Sul, RS. Bol Div Fom Prod Min, Rio de Janeiro, DNPM, 1966, 127: 1-232.

SOLIANi JR. E. 1986. Os dados geocronológicos do Escudo Sul-rio-grandense e suas implicações de ordem geotectônica. São Paulo, Tese de Doutorado em Geociências, $425 \mathrm{p}$.

STRECKEISEN AL. 1976. To each plutonic rock, its proper name. Earth Sci Rev 12: 1-33.

THOMPSON RN, MORRISON MA, HENDRY GL AND PARRY SJ. 1984. An assessment of the relative roles of crust and mantle in magma genesis: an elemental approach. Phil Trans R Soc Lon A 310: 549-590. 